\title{
A Note on Translations \\ AND TEXTS
}

I have translated portions of Aristotle's Politics from the text edited by Alois Dreizehnter, consulting the translations of Ernest Barker, Carnes Lord, W. L. Newman, and H. Rackham. In translating from the Nicomachean Ethics I used the text edited by Franciscus Susemihl and consulted the translations of Terence Irwin, H. Rackham, and W. D. Ross. My translations of Aristotle's other works were generally from the texts provided by the Loeb editions; I consulted the Loeb translations and those of the Clarendon Aristotle Series. For full and specific references, see the Bibliography. Any emphasis in quotations of Aristotle is mine. Quotations of Plato's Republic and the Laws are from Allan Bloom's translation (New York: Basic Books, 1968) and Thomas L. Pangle's translation (New York: Basic Books, 1980), respectively. Translations of commentary in French are my own. The quotation from Joachim Ritter's Metaphysik und Politik in the Appendix, "Premises of Interpretation," was translated with help from a Berlitz Language Center.

I use the following abbreviations for Aristotle's works:

AC The Athenian Constitution

$D A$ On the Soul (De Anima)

EE Eudemian Ethics

GA Generation of Animals

HA Historia Animalium

Met Metaphysics 


\section{Magna Moralia \\ NE Nicomachean Ethics \\ Oec Oeconomica \\ PA Parts of Animals \\ Ph Physics \\ Pol Politics \\ Rh The "Art" of Rhetoric \\ Top Topics}

References to Aristotle's texts are to the Bekker line numbers as found in Dreizehnter's edition of the Politics, Susemihl's edition of the Nicomachean Ethics, and the Loeb editions of other works. I also refer to the chapter and section divisions found in the same editions. References appear in order of importance; clusters of references are intended to be considered together (though some numbers may refer to the same point). 
The Public and the Private

in Aristotle's

Political Philosophy 
